University of Nebraska - Lincoln

DigitalCommons@University of Nebraska - Lincoln

USDA Forest Service / UNL Faculty Publications U.S. Department of Agriculture: Forest Service -National Agroforestry Center

2012

Integrating LANDIS model and a multi-criteria decision-making approach to evaluate cumulative effects of forest management in the Missouri Ozarks, USA

\author{
ZongBo Shang \\ University of Missouri \\ Hong S. He \\ University of Missouri \\ Weimin Xi \\ University of Wisconsin-Madison \\ Stephen R. Shifley \\ USDA Forest Service \\ Brian J. Palik \\ USDA Forest Service
}

Follow this and additional works at: https://digitalcommons.unl.edu/usdafsfacpub

Part of the Forest Sciences Commons

Shang, ZongBo; He, Hong S.; Xi, Weimin; Shifley, Stephen R.; and Palik, Brian J., "Integrating LANDIS model and a multi-criteria decision-making approach to evaluate cumulative effects of forest management in the Missouri Ozarks, USA" (2012). USDA Forest Service / UNL Faculty Publications. 162.

https://digitalcommons.unl.edu/usdafsfacpub/162

This Article is brought to you for free and open access by the U.S. Department of Agriculture: Forest Service -National Agroforestry Center at DigitalCommons@University of Nebraska - Lincoln. It has been accepted for inclusion in USDA Forest Service / UNL Faculty Publications by an authorized administrator of DigitalCommons@University of Nebraska - Lincoln. 


\title{
Integrating LANDIS model and a multi-criteria decision-making approach to evaluate cumulative effects of forest management in the Missouri Ozarks, USA
}

\author{
ZongBo Shang ${ }^{\mathrm{a}, *}$, Hong S. He ${ }^{\mathrm{a}}$, Weimin Xi ${ }^{\mathrm{b}, * *}$, Stephen R. Shifley ${ }^{\mathrm{c}}$, Brian J. Palik ${ }^{\mathrm{d}}$ \\ a Department of Forestry, University of Missouri, Columbia, MO 65211, USA \\ ${ }^{\mathrm{b}}$ Department of Forest and Wildlife Ecology, University of Wisconsin-Madison, Madison, WI 53706, USA \\ ' Sustainable Management of Central Hardwood Ecosystems and Landscapes, USDA Forest Service, Northern Research Station, Columbia, MO 65211, USA \\ d Center for Research on Ecosystem Change, USDA Forest Service, Northern Research Station, Grand Rapids, MN 55744, USA
}

\section{A R T I C L E I N F O}

\section{Article history:}

Available online 17 September 2011

\section{Keywords:}

Decision support system

Habitat suitability index

LANDIS

PROMETHEE

Mark Twain National Forest

The Missouri Ozarks

\begin{abstract}
A B S T R A C $T$
Public forest management requires consideration of numerous objectives including protecting ecosystem health, sustaining habitats for native communities, providing sustainable forest products, and providing noncommodity ecosystem services. It is difficult to evaluate the long-term, cumulative effects and tradeoffs these and other associated management objectives. To demonstrate the capabilities of techniques suitable to support such evaluations we combined a spatially explicit landscape-scale, succession and disturbance model (LANDIS) with wildlife habitat suitability models and a multi-criteria decisionmaking framework to compare four management alternatives across a $700 \mathrm{~km}^{2}$ area of the Mark Twain National Forest in Missouri, USA. We estimated the combined, cumulative effects of tree species succession, fire disturbance, fuel accumulation, fire hazard, wind disturbance and timber harvest on future species composition, age class distribution, timber products, and wildlife habitat suitability for eastern wild turkey and eastern gray squirrel. We applied a structured, multi-criteria, decision-making framework (PROMETHEE) to analyse forest conditions and to derive weighted composite scores for seven criteria applied to each alternative management scenario. The approach provides a systematic, repeatable, transparent, spatially explicit framework for evaluating the long-term, landscape-scale cumulative effects of management alternatives. The methodology does not encompass all the factors that influence decisions about public land management, but it captures many important ones. The underlying models provide a way to test and accumulate knowledge about forest response to succession and disturbance and to use those relationships to support decision making with the best available science.
\end{abstract}

(c) 2011 Elsevier B.V. All rights reserved.

\section{Introduction}

The Mark Twain National Forest Revised Land and Resource Management Plan was prepared for Missouri's only National Forest, in accordance with the Forest and Rangeland Renewable Resources Planning Act of 1974 (Mark Twain National Forest, 2005). In this plan, forestwide goals and objectives include: (1) promoting ecosystem health and sustainability, which includes maintaining, enhancing or restoring site-appropriate native natural communities, preventing new invasions and controlling or reducing existing occurrences of non-native invasive species, restoring and maintaining soil productivity and nutrient retention capacity, protecting the water quality and integrity of watershed of the forest lands, and providing and restoring the range and quality of natural habitats for

\footnotetext{
* Corresponding author at: University of Wyoming, Laramie, WY 82071, USA. ** Corresponding author at: University of Wisconsin-Madison, Madison, WI 53706, USA.

E-mail addresses: zshang1@uwyo.edu (Z. Shang), wxi3@wisc.edu (W. Xi).
}

wildlife and aquatics; (2) providing a variety of uses, values, products and services, which include offering multiple public values, using prescribed fires and other fire management to reduce hazardous fuels and wildland fire risk to communities, developing and maintaining a transportation system, and sustainable production of timber and wood products.

The complexities of developing a national forest management plan are similar to complexities of forest ecosystem management in general. Forest ecosystem management addresses issues of large spatial scales and long time frames, and requires sound management decisions that are socially acceptable, economically feasible, and ecologically sustainable (Rauscher, 1999). Sustainability of forest productivity, biogeochemical cycles and biological diversity has often been emphasized as a goal for managing National Forests in the United States (Meyer and Swank, 1996).

Computer-based forest growth and yield models and planning models (e.g., FORPLAN) have been heavily relied on to implement computing algorithms to address the complex problems of landscape-scale planning (Johnson et al., 1986). Planning questions have become increasingly complex and broader in scale, requiring 
attention to mores issues and ecosystem interactions than in the past. However, these multiple tasks severely stretched the capabilities and design intent of traditional growth and yield models and planning models (Kent et al., 1991). For example, linear programming in FORPLAN has been reported to be unsuitable for site-specific, tactical planning (Weintraub et al., 2004). Moreover "high levels of spatial aggregation tend to be used, which leaves a great deal of uncertainty as to how to spatially distribute or disaggregate solutions" (Church et al., 2000). Therefore, even though the FORPLAN model (Version 2.0) is still used as a forest management planning tool, forest simulation models (in a sense, more strictly ecological models) can be applied to provide additional scientific analyses of the complex problems involved in forest ecology and management planning (Mladenoff, 2004; Xi et al., 2009).

Within the last three decades, numerous forest simulation models have been developed to incorporate the concepts and theories of ecological succession, disturbance, and equilibrium and nonequilibrium ecological systems (Mladenoff and Baker, 1999; He, 2008; Xi et al., 2009). These include: (1) forest gap models, e.g., JABOWA model (Botkin et al., 1972), FOREST (Ek and Monserud, 1974), FORET (Shugart, 1984), SORTIE (Pacala et al., 1993); (2) forest growth and management models, e.g., FVS (Wykoff et al., 1982; Dixon, 2002; Crookston and Dixon, 2005); (3) disturbance models, e.g., BEHAVE (Andrews, 1986) and FVS-FFE (Beukema et al., 1997); and (4) landscape models, e.g., LANDIS (Mladenoff et al., 1993, 1996; Mladenoff and He, 1999; He et al., 2004) and LANDSIM (Roberts and Betz, 1999). FVS has been widely applied for standlevel simulations (e.g., Teck et al., 1996; Bragg, 2000; Farnden, 2000; Torgersen, 2001; Schwalm and Milner, 2002; Gilmore, 2003; Lacerte et al., 2004, 2006; Johnson and Peterson, 2005; Treiman et al., 2005) and for landscape simulations encompassing more than 10,000 ha (Crookston and Stage, 1991). LANDIS has been widely applied on forest landscapes exceeding one million ha in extent to simulate forest development and management which often includes succession, abiotic disturbance (e.g., wildfire, windthrow), biological disturbance (e.g., insects), timber harvest, and fire management (e.g., He et al., 2002, 2004, 2005a,b; Gustafson et al., 2000, 2004; Franklin et al., 2001; Shang et al., 2004; Xi et al., 2008, 2009).

Sustainable forest management often depends on successful integration of economic, ecological and social goals, and such integration is a complex process (Kohm and Franklin, 1997). Decision support system (DSS) has been developed to provide structured analysis for solving complex silvicultural decision problems within multiple-purpose forestry (e.g., Tarp and Helles, 1995; Llewellyn et al., 1996; Kolström and Lumatjärvi, 1999; Varma et al., 2000; Hunt and Haider, 2001; Seely et al., 2004; Anderson et al., 2005; Kangas and Kangas, 2005). By combining decision support systems and forest simulation models together, forest managers can more effectively analyse the joint effects of management on forest productivity and services (e.g., timber), forest restoration (e.g., habitat quality), and to thereby help managers find suitable management practices for multiple objectives across multiple temporal and spatial scales.

This study integrated a spatially explicit forest landscape model (LANDIS 4.0, He et al., 2004), a landscape habitat suitability model (HSI model, Larson et al., 2003) and a multi-criteria decisionmaking approach (PROMETHEE, Brans and Mareschal, 2005) to evaluate management alternatives for a section of the Mark Twain National Forest in Missouri, USA. More specifically, we chose four forest management alternatives outlined by the Mark Twain National Forest in 2005, and we conducted a 200-year simulation to address the following factors: (1) estimated costs for management efforts (e.g., even- and uneven-age harvest, pine planting, thinning and prescribed burning) and general forest outputs (e.g., timber products); (2) dynamics of forest species and age class composition, (3) fuel accumulation, fire hazards and fire events, and (4) habitat suitability for two wildlife species: eastern wild turkey (Meleagris gallopavo silvestris), an important game species; and eastern gray squirrel (Sciurus carolinensis), a common mammal in oak-hickory forests. Finally, we used a decision support system to combine multiple factors and analyse relative preferences for the alternative management practices. A decision support system can provide a structured framework for identifying and quantifying multiple management objectives and analyzing the relative capacity of alternative forest management plans to meet them collectively. Or goal was to determine the strengths and limitations associated with: (1) combining the LANDIS forest vegetation succession and disturbance model with habitat suitability models to make detailed simulations of multiple outputs from complex management alternatives applied to a real landscape; and with (2) application of the PROMETHEE decision support system to compare the capacity of alternative management plans to simultaneously meet multiple management objectives.

\section{Methods}

\subsection{Study area}

The Mark Twain National Forest is located in southern Missouri, lying mostly in the Ozark Plateau and encompassing about $6000 \mathrm{~km}^{2}(1,487,000$ acres $)$ of forest land. Our study area is located in the Eleven Point Unit of the Mark Twain National Forest (Fig. 1A), a section of about $700 \mathrm{~km}^{2}$ in the National Forest located in the southeastern Missouri Ozark Highlands within the Current River Hills Subsection (Nigh and Schroeder, 2000). The study area includes large, contiguous blocks of National Forest land surrounded by (and in some areas intermixed with) state and private forest ownerships. We selected this area for our study because ecological land types and species composition information are readily available in the study area (e.g., Miller, 1981; Brookshire and Shifley, 1997; Shifley and Brookshire, 2000; Shifley et al., 2000a,b) and fire history has been well documented (e.g., Haines et al., 1972; Westin, 1992; Guyette and Larsen, 2000; Guyette et al., 2002).

Historically, the landscape was dominated by white oak (Quercus alba L.), black oak (Quercus velutina Lam.), scarlet oak (Quercus coccinea Muenchh.), post-oak (Quercus stellata Wangenh.) and shortleaf pine (Pinus echinata Mill.) in the steep, rocky and dry sites, and a mixture of the trees in the red oak and white oak groups, maples (Acer rubrum L., Acer saccharum Marsh.), and numerous species of lesser abundance in the mesic hills (Batek et al., 1999). Heavy logging between 1890 and 1920 (Guyette and Larsen, 2000) and fire suppression since 1940 (Guyette et al., 2002) have favored the subsequent development of mixed-oak forests in the region with decreased abundance of shortleaf pine relative to the mid 19th century (Batek et al., 1999; Table 1). Present-day forests are predominantly mixtures of white oak, post oak, black oak, scarlet oak, hickory (Carya spp.) and shortleaf pine (Fig. 2).

\subsection{Forest management alternatives}

The Mark Twain National Forest 2005 Plan Revision outlines a range of alternatives (management prescriptions) to address the diverse forest management issues and guide natural resource management activities on the forest (Mark Twain National Forest, 2005). For this analysis we selected four of those management alternatives and modeled them as closely as possible (Table 2). Additional details about the management alternatives can be found in the Land and Resource Management Plan (Mark Twain National Forest, 2005). Based on the management prescriptions and their related maps, we digitized maps of initial 


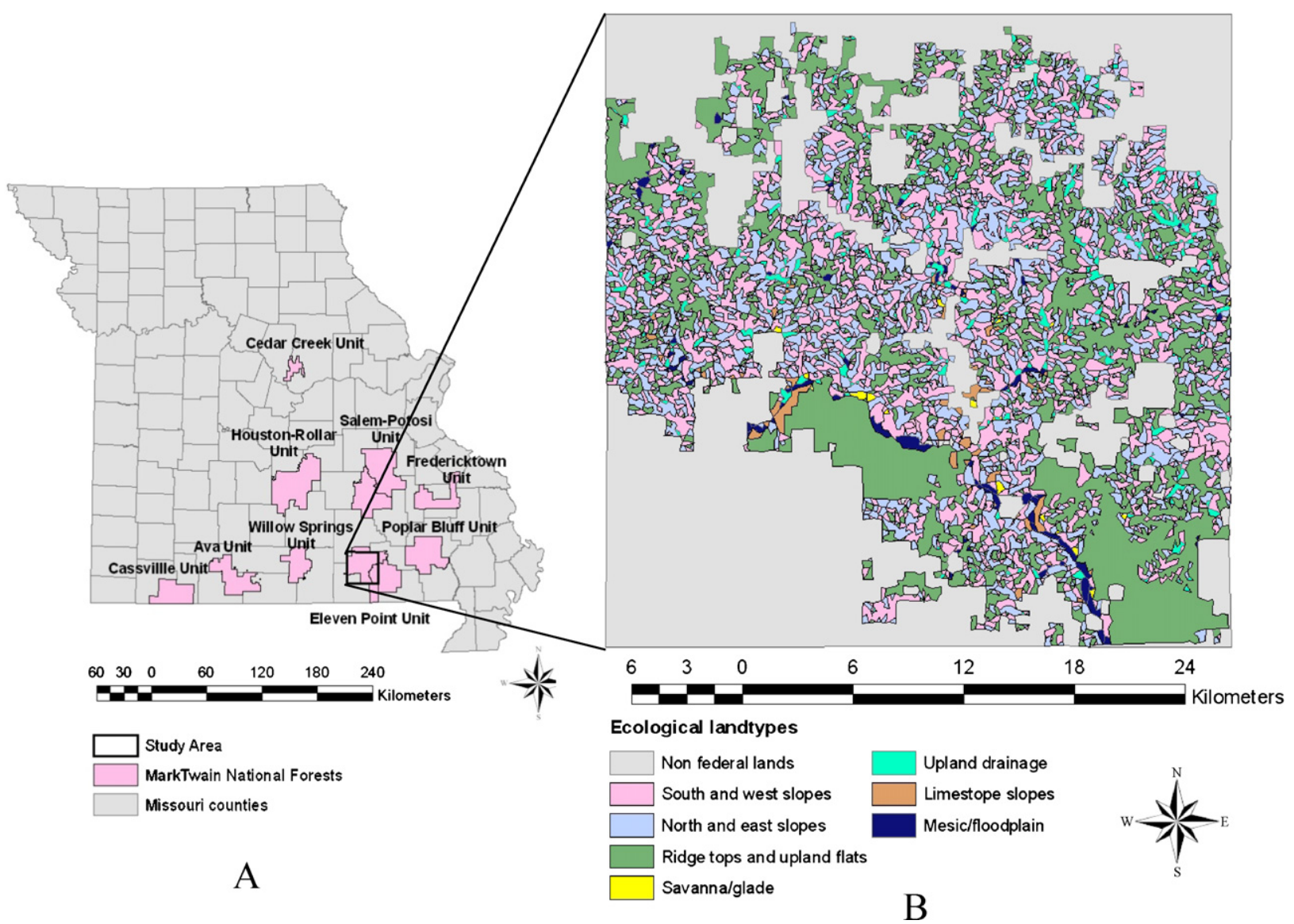

Fig. 1. Study area and the ecological land types. A: Study area within the Mark Twain National Forest; B: Ecological land types in the study area.

forest conditions and management emphasis for each alternative (Fig. 3).

Alternative 1 (Fig. 3A, Table 2) is designed to emphasize natural succession, limited active forest management, and semi-primitive recreation over timber production. This alternative minimizes direct human influence, and timber harvesting is a byproduct of habitat restoration goals. Forests would be affected primarily by natural processes such as succession and disturbances (e.g., insects, disease, wildfire, and weather events).

Alternative 2 (Fig. 3B, Table 2) emphasizes maintaining composition, structure and dynamics of native forest ecosystems, aggressively restoring native terrestrial communities, and restoring oak-pine forests on a large-scale. The focus is on restoration of underrepresented terrestrial natural communities while providing forest products and other multiple benefits. Some management activities (e.g., timber harvest and prescribed fire) would be used to influence ecological processes and sustain a high diversity of habitats and species.

Alternative 3 (Fig. 3C, Table 2) is designed to balance restoration of natural communities with production of traditional forest commodities. Emphasis is on improving forest health, production of forest products and other multiple use benefits, and enhancement of terrestrial natural communities. Some management activities (e.g., timber harvest and prescribed fire) are used to mimic ecological processes to attain and sustain a high diversity of habitats and species. Alternative 3 intends to provide a wide range of wildlife habitats through restoring and enhancing terrestrial natural communities, and emulating their historic distribution patterns.

Alternative 4 (Fig. 3D, Table 2) emphasizes traditional forest management and production of forest commodities. The focus is on ecosystem enhancement while providing utilization of forest resources.

In general, all four alternatives have the similar allocation of designated wilderness area (prescription 5.1) and riparian zone along the Eleven Point River (prescription 8.1), and the same non-federal lands (prescription 0 ). The differences among those alternatives are area allocated for restoration and recreation (prescription 1.1), general forest (prescription 2.1), and semi-primitive non-motorized (prescription 6.1) or motorized recreation opportunity spectrum objectives. Area allocation by management type for each alternative is compared in Table 2. Additional details about the timber harvest, pine plantation, commercial thinning and prescribed burning assigned for each alternative can be found in Table 3 .

\section{Table 1}

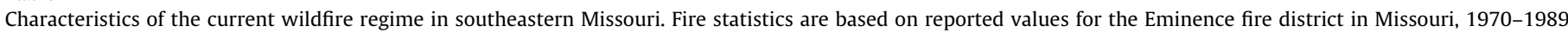
(Westin, 1992).

\begin{tabular}{|c|c|c|c|c|c|c|}
\hline \multirow[t]{2}{*}{ Mean fire-return interval } & \multicolumn{4}{|c|}{ Fire size classes } & \multirow[t]{2}{*}{ Average fire size (ha) } & \multirow{2}{*}{$\begin{array}{l}\text { Number of fire per } \\
\text { million ha per year }\end{array}$} \\
\hline & $<0.1$ ha & 0.1 to $<4$ ha & 4 to $<40$ ha & $\geq 40$ ha & & \\
\hline $400-500$ years & $26 \%$ & $55 \%$ & $17 \%$ & $2 \%$ & 4.4 & 474 \\
\hline
\end{tabular}




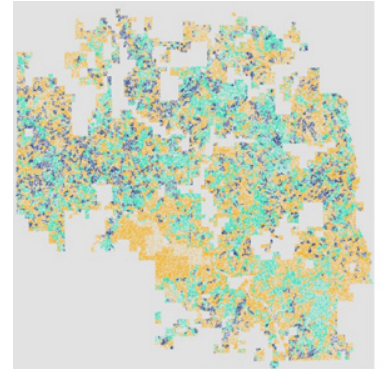

White oak group

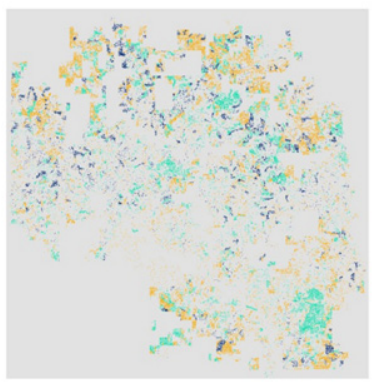

Pine group

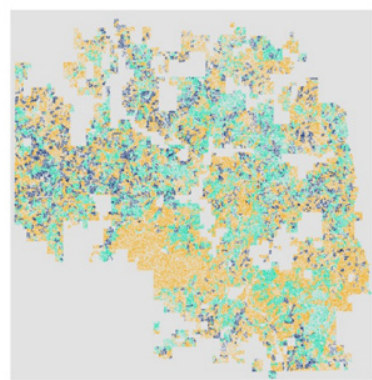

Red oak group

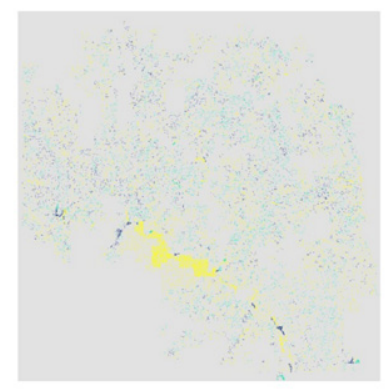

Maple group
Age cohorts
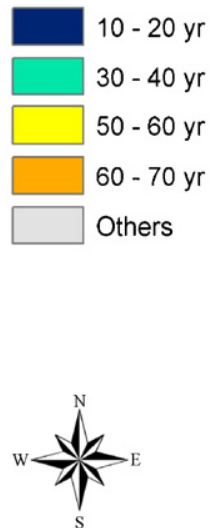

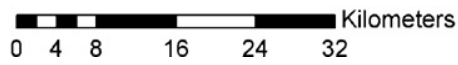

Fig. 2. Species composition in our study area.

Table 2

Comparison of areas by square kilometers allocated to management alternatives in the study area.

\begin{tabular}{|c|c|c|c|c|c|}
\hline Code & Management prescription & Alternative 1 & Alternative2 & Alternative 3 & Alternative 4 \\
\hline 0 & Non-federal lands & 473 & 473 & 473 & 473 \\
\hline 1.1 & $\begin{array}{l}\text { Restoration of natural communities while providing a roaded-natural } \\
\text { recreation experience }\end{array}$ & 55 & 483 & 264 & 55 \\
\hline 2.1 & $\begin{array}{l}\text { General forest - management for multiple use resource objectives } \\
\text { while allowing for enhancement of natural communities, } \\
\text { improvement of forest health conditions, and road and natural } \\
\text { recreation experiences }\end{array}$ & 0 & 6 & 225 & 434 \\
\hline 5.1 & Designated wilderness & 72 & 72 & 72 & 72 \\
\hline 6.1 & $\begin{array}{l}\text { Semi-primitive non-motorized dispersed recreation emphasis, with } \\
\text { limited investments in management of natural vegetative } \\
\text { communities }\end{array}$ & 78 & 0 & 0 & 0 \\
\hline 6.2 & $\begin{array}{l}\text { Semi-primitive motorized dispersed recreation experience emphasis, } \\
\text { with limited investments in management of natural vegetative } \\
\text { communities }\end{array}$ & 408 & 52 & 52 & 52 \\
\hline 8.1 & Designated 'special areas' other than wilderness & 72 & 72 & 72 & 72 \\
\hline Total & & 1158 & 1158 & 1158 & 1158 \\
\hline
\end{tabular}

Table 3

Management prescription (per decade) for each management alternative as derived from the Mark Twain National Forest Plan (Mark Twain National Forest, 2005).

\begin{tabular}{|c|c|c|c|c|c|c|c|}
\hline & & 1.1 & 2.1 & 5.1 & 6.1 & 6.2 & 8.1 \\
\hline \multirow[t]{3}{*}{ Rotation age (years) } & White oaks & 120 & 120 & $\mathrm{~N} / \mathrm{A}$ & 90 & 90 & $\mathrm{~N} / \mathrm{A}$ \\
\hline & Pines & 100 & 70 & $\mathrm{~N} / \mathrm{A}$ & 70 & 70 & $\mathrm{~N} / \mathrm{A}$ \\
\hline & Red oaks & 80 & 70 & $\mathrm{~N} / \mathrm{A}$ & 70 & 70 & $\mathrm{~N} / \mathrm{A}$ \\
\hline \multirow[t]{3}{*}{ Regeneration harvest } & Harvest method & $\begin{array}{l}\text { Even-aged, clearcut } \\
\text { or shelterwood }\end{array}$ & $\begin{array}{l}\text { Even-aged, clearcut } \\
\text { or shelterwood }\end{array}$ & $\mathrm{N} / \mathrm{A}$ & $\begin{array}{l}\text { Uneven-aged, } \\
\text { group selection }\end{array}$ & $\begin{array}{l}\text { Even-aged, clearcut } \\
\text { or shelterwood }\end{array}$ & $\mathrm{N} / \mathrm{A}$ \\
\hline & Target area & $8 \%$ & $11 \%$ & $\mathrm{~N} / \mathrm{A}$ & $3 \%$ & $5 \%$ & $\mathrm{~N} / \mathrm{A}$ \\
\hline & Stand size limit (ha) & 16 & 16 & $\mathrm{~N} / \mathrm{A}$ & 6 & 6 & $\mathrm{~N} / \mathrm{A}$ \\
\hline Pine plantation & Percent of oak-pine & $10 \%$ & $2 \%$ & $\mathrm{~N} / \mathrm{A}$ & $\mathrm{N} / \mathrm{A}$ & $\mathrm{N} / \mathrm{A}$ & $\mathrm{N} / \mathrm{A}$ \\
\hline \multirow[t]{4}{*}{ Commercial thinning } & Minimum age (years) & 35 & 35 & $\mathrm{~N} / \mathrm{A}$ & 50 & 50 & $\mathrm{~N} / \mathrm{A}$ \\
\hline & Interval (years) & 20 & 20 & $\mathrm{~N} / \mathrm{A}$ & 20 & 20 & $\mathrm{~N} / \mathrm{A}$ \\
\hline & Residual basal area & 60 & 70 & $\mathrm{~N} / \mathrm{A}$ & 70 & 70 & $\mathrm{~N} / \mathrm{A}$ \\
\hline & Percent management area & $8.5 \%$ & $8.5 \%$ & $\mathrm{~N} / \mathrm{A}$ & $6 \%$ & $6 \%$ & $\mathrm{~N} / \mathrm{A}$ \\
\hline \multirow[t]{2}{*}{ Prescribed burning } & Percent of management area & $20 \%$ & $10 \%$ & $\mathrm{~N} / \mathrm{A}$ & $\mathrm{N} / \mathrm{A}$ & $\mathrm{N} / \mathrm{A}$ & $\mathrm{N} / \mathrm{A}$ \\
\hline & Interval (years) & 10 & 10 & $\mathrm{~N} / \mathrm{A}$ & $\mathrm{N} / \mathrm{A}$ & $\mathrm{N} / \mathrm{A}$ & $\mathrm{N} / \mathrm{A}$ \\
\hline
\end{tabular}



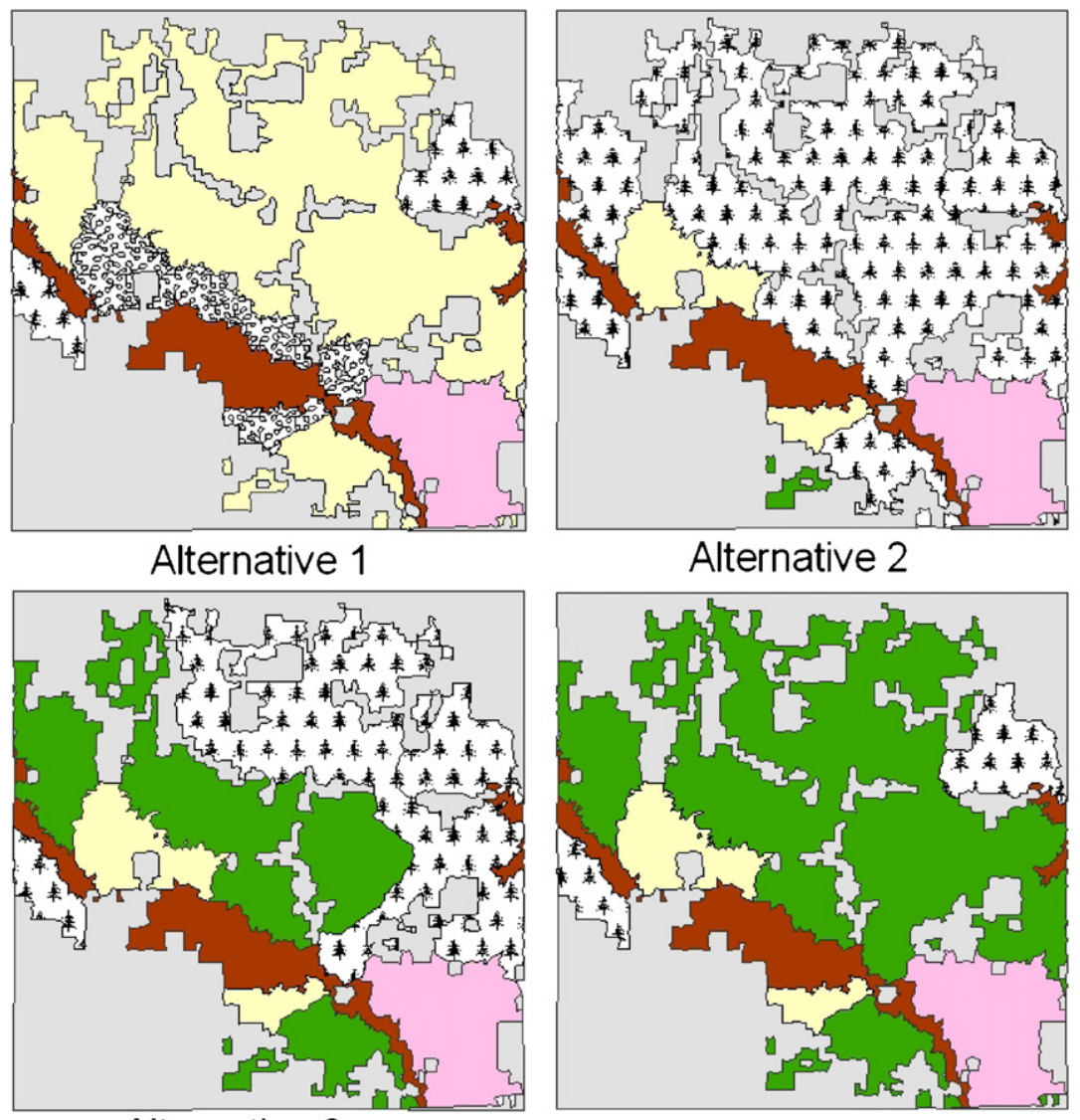

Alternative 3

\section{Management Areas}

Alternative 4

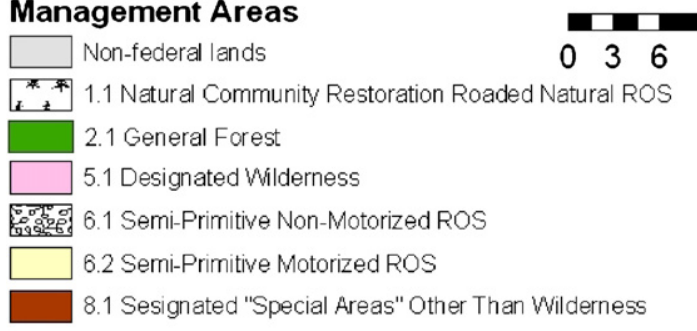

12

18 24

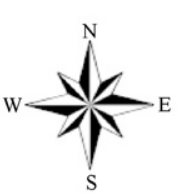

Fig. 3. Four management plans (Alternatives 1-4) in the study area. Modified from the Mark Twain National Forest (2005).

\subsection{LANDIS model}

LANDIS (Mladenoff et al., 1996; Mladenoff and He, 1999; He et al., 2005a,b) is a spatially explicit landscape model designed to simulate forest landscape change over large spatial $\left(10^{3}-10^{7}\right.$ ha $)$ and long temporal $\left(10^{1}-10^{3}\right.$ years) scales. LANDIS 4.0 can simulate the dynamics of: (1) forest succession and seed dispersal, (2) fuel accumulation and decomposition, (3) fire, wind and biological disturbance (insects and diseases), and (4) timber harvest, thinning and fire management. LANDIS 4.0 can simulate the large-scale statistical properties of landscape composition, such as age structure and spatial pattern under particular disturbance and management regimes. But it does not predict the time and location of individual disturbance events in a tactical sense (e.g., such as would be needed to manage insect invasions or wildfires). Neither does it identify the year and location nor optimize the spatial or temporal distribution of management events. Rather, it is a scenario simulation model that compares longterm, large-scale, cumulative effects of user-defined disturbance and management scenarios on real or hypothetical landscapes. The following paragraphs contain a brief description of LANDIS 4.0. Detailed information about LANDIS 4.0 design can be found in previous research papers (e.g. He et al., 2005a; Shang et al., 2007 and online http://web.missouri.edu/ umcsnrlandis/).

\subsubsection{Modeling species succession and seed dispersal}

Tree species succession at each site $\left(30 \times 30 \mathrm{~m}^{2}\right.$ in this study) is modeled in LANDIS as a competitive process driven by species life history attributes, including longevity, sexual maturity, shade tolerance, vegetative reproduction (sprouting) probability and seeding capability. In contrast to gap models which track succession dynamics for individual trees (e.g., Botkin et al., 1972; Ek and Monserud, 1974; Shugart, 1984; Pacala et al., 1993), LANDIS treats a landscape as a grid of sites (or cells) with vegetation information stored as attributes for each cell. For each site, individual species are tracked by presence/absence of 10-year age cohorts. Succession dynamics are simplified as a process including seed dispersal and establishment, vegetative reproduction, growth, death (when reaching longevity), and mortality caused by disturbance. 
LANDIS models seed dispersal by species is based on the estimated effective $\left(P_{\text {seed dispersal }}>0.95\right)$ and maximum $\left(P_{\text {seed dispersal }}<0.001\right)$ seed dispersal distances (He and Mladenoff, $1999 b)$ seed dispersal probability $\left(P_{\text {seed dispersal }}\right)$ between the effective (ED) and maximum seed distance (MD) follows a negative exponential distribution (He and Mladenoff, 1999b):

$P_{\text {seed dispersal }}=e^{-b_{1}\left(\frac{\mathrm{Dis}}{\mathrm{MD}}\right)}$

where Dis is a given distance from the seed source (MD $>$ Dis $>E D$ ), and $b_{1}$ is an adjustable coefficient $\left(b_{1}>0\right)$ that can be adjusted by species.

The LANDIS model estimates the available light and other environmental conditions at a site (which are summarized by ecological land types) and uses that information to determine whether the dispersed seeds become established as new tree cohorts. A species establishment probability is empirically parameterized by species and land type to differentiate reproductive success among land types and is implemented via a Bernoulli trial conducted for each establishment event. Vegetative reproduction (or sprouting) is common for the hardwood species in the study region following mortality caused by harvest, fire or wind. Sprouting probabilities are estimated by species and ecological land type and are implemented using a Bernoulli trial when a tree cohort dies.

Growth of surviving tree cohorts is incremented via 10-year age increments, because we applied the LANDIS model with a 10year time step. Age-dependent mortality increases as cohorts reach maximum longevity. Mortality caused by disturbance (e.g., fire, windthrow, insect and disease), is modeled based on the disturbance intensity, species tolerance and age-specific susceptibility.

\subsubsection{Fuel}

Two types of dead fuels (fine fuels and coarse fuels) as well as live fuels are modeled in LANDIS. Fine fuels correspond to 1 and 10$\mathrm{h}$ lag fuels and litter. Coarse fuels, also called coarse woody debris (CWD), correspond to 100 and 1000-h fuels and include snags, logs, large pieces of wood (which result from the disintegration of larger snags and logs), branches, stems and coarse roots. Live fuels consist of leaves, twigs, and stems of growing plants. Most live fuels are difficult to ignite and often do not burn readily by themselves. However, some conifer species provide vertical continuity between canopy layers and allow fire to move from surface fuels or understory vegetation to tree crowns.

In the LANDIS model, fine fuel loads are approximated by species composition and species-specific age cohorts. In general, mature, old trees produce more needles, leaves, and dead twigs than small, young trees. An empirical curve is defined for each species to approximate how fuel loads at a specific site varying by species composition and age class. Fine fuel from different species may have different flammability due to differences in physical and chemical attributes, so a fuel quality coefficient $(0<\mathrm{FQC} \leq 1)$ is assigned for each species to summarize those differences on a relative scale. Fine fuel loads for each species are weighted differently by FQC and aggregated together to calculate the total fine fuel loads for each site. Experimental studies (Mudrick et al., 1994; Trofymow et al., 2002) suggest that most of the fine fuels decompose in less than 10 years. Therefore, the LANDIS fuel module assumes that most fine fuels decompose within the 10-year model time step, so it re-calculates fine fuel loads for each decade of the simulation.

Coarse fuel loads are approximated using stand age (the oldest age cohorts one the site) in combination with disturbance history (e.g., time since last disturbance). In the absence of disturbance, the accumulation process dominates until the amount of coarse fuel reaches a level where decomposition and accumulation are estimated to be in balance. When a disturbance is simulated (e.g., windthrow, insect defoliation, or harvest), additional coarse fuels are added into the coarse fuel pool for affected sites. Those extra coarse fuels are modeled to decompose over subsequent decades with faster decomposition on mesic land types and slower decomposition on xeric land types. This decomposition process is modeled based on an empirical decomposition curve. The accumulation and decomposition processes together determine the coarse fuel loads.

Some live fuels (e.g., conifers), provide vertical continuity between vertical strata and allow fire to be transmitted from surface to crowns of trees or shrubs. LANDIS does not track the loads of live fuels. Instead, LANDIS only tracks the presence of those live fuels which can become ladder fuels and introduce crown fires. Then during a simulated fire event, LANDIS uses a Bernoulli trial to stochastically model the presence or absence of a crown fire at a given site.

\subsubsection{Fire}

LANDIS 4.0 integrates a statistical fire ignition model used in earlier versions of LANDIS (He and Mladenoff, 1999a; Yang et al., 2004; He et al., 2005a,b) and a fire spread model based on FARSITE (Finney, 1998 ) to simulate fire behavior, including fire ignition/occurrence, size, spread, intensity and severity.

For each potential ignition point, LANDIS 4.0 performs a Bernoulli trial against a probability of fire initiation $(p)$ to determine whether a simulated fire is ignited. Following Johnson and Van Wagner (1985) and Baker (1992), LANDIS 4.0 uses the mean fire-return interval (FR) and time since last fire (FT) to estimate the probability of fire initiation $(p)$ :

$p=1-e^{\left(-\frac{\mathrm{FT}}{\mathrm{FR}}\right)}$

Fire size often follows a log-normal distribution (He and Mladenoff, 1996a), with small fires occurring more frequently than large fires.

FARSITE (Finney, 1998) upgraded an elliptically shaped model with a physical model (Reinhardt et al., 1997), and developed a minimum travel-time method to simulate fire spread. LANDIS 4.0 follows the FARSITE model (Finney, 1998, 2002) and incorporates a minimum travel-time algorithm to simulate fire spread. Detail equations can be found in Finney (2002).

The combination of fine and coarse fuel loads as well as live fuels has been used to define the potential fire intensity classes (1-5), which in combination with the prevailing wind direction, controls the modeled rate of fire spread across the landscape. The final simulated rate of fire spread is the product of a fuel coefficient (which is determined based on potential fire intensity from class 1 to 5 ) and the fire spread rate calculated from prevailing wind using Finney's algorithm (2002). As described above, the fire spread size is stochastically generated from a log-normal distribution. LANDIS uses species fire-tolerance, species age class, and fire intensity together to determine the fire severity and associated mortality by tree species and age class (He and Mladenoff, 1999a). In detail, fire is a bottom-up disturbance event; other things being equal, younger (smaller) trees have a greater probability of mortality from a fire of given intensity than do older (larger) trees. Also, fire tolerance varies among species. To implement these two characteristics, species fire tolerance classes, containing five categories from 1 to 5 , are designed to reflect the differences in fire tolerance among species. Species-specific fire-susceptibility classes are designed to reflect differences in fire-caused mortality related to age. Susceptibility class 1 includes the youngest age classes that are most susceptible to fire-caused mortality, and class 5 includes the oldest and the least susceptible trees. Species-specific fire tolerance classes combined with age-specific fire-susceptibility classes determine whether a species cohort of a certain age can survive a fire event of a given intensity class. Additional details and examples can be found in He and Mladenoff (1999a). 


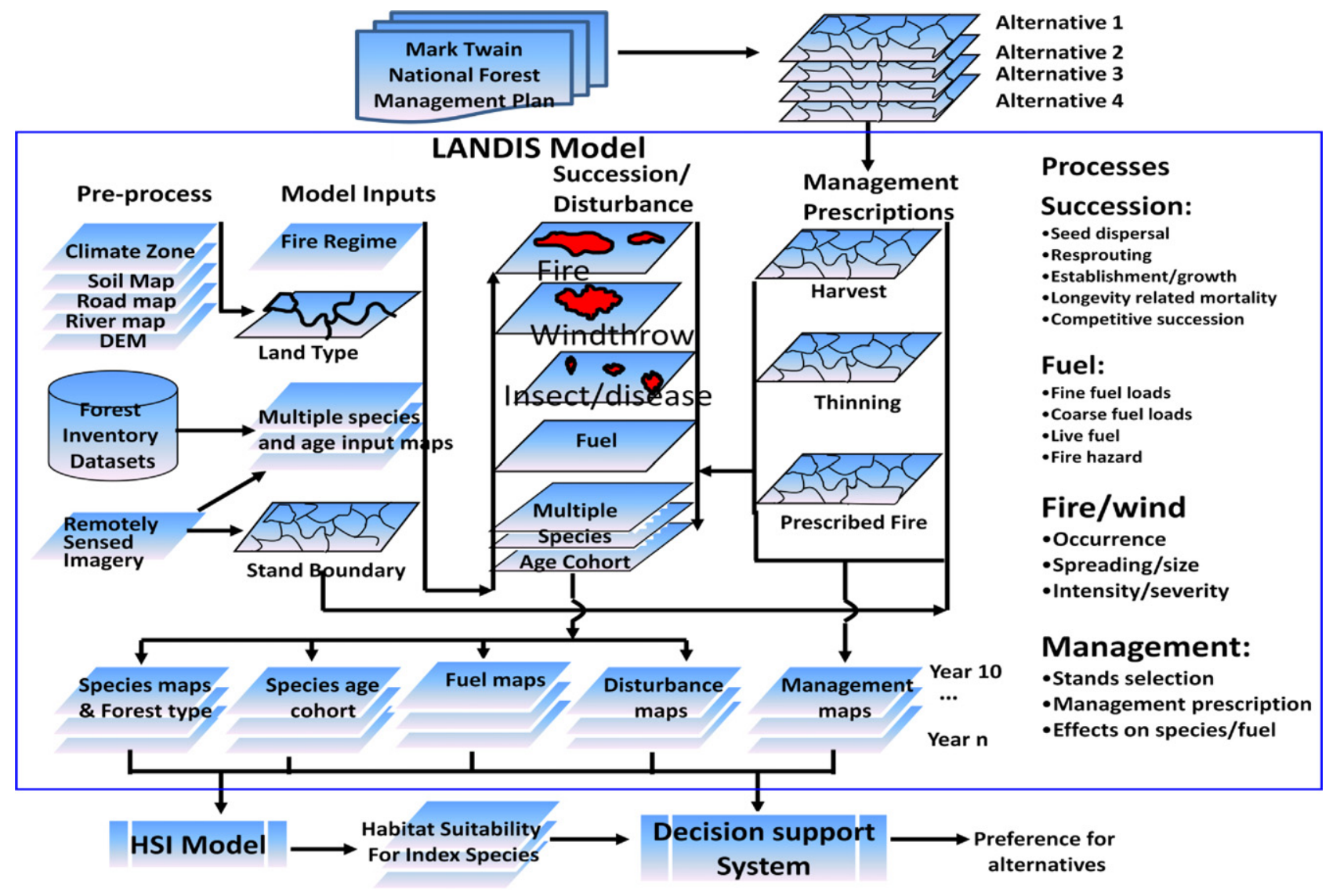

Fig. 4. A flowchart that shows the process of this study. This flowchart was modified from He et al. (2005a,b).

\subsubsection{Forest management}

The LANDIS harvest module (Gustafson et al., 2000) was applied to model timber harvest, thinning and prescribed burning on the forest landscape. Management alternatives differed by the location, amount, and type of harvest by decade. Timber harvesting prescriptions differed by management alternative and management area (Fig. 3, Table 3) with adjacency constraints included to disperse the location of even-aged harvests (e.g., to ensure two or more clearcuts were not spatially adjacent in a given decade) and the location of group regeneration openings within stands treated with uneven-aged management.

Land type, fire, wind disturbance, timber harvest, thinning and prescribed burning could also affect fuel loads (He et al., 2005a,b). For example, fine fuel decomposition rates varied by land types. Thus, a land type modifier was applied to decrease or increase the fine fuel derived from species age cohorts. Disturbances may increase or decrease the fuel loads in a similar way. Fire events can reduce the fine and coarse fuel, while wind disturbances often increase coarse fuel. A fine fuel and coarse fuel modifier was used to modify how disturbance affected fuels depending upon the type and intensity of the event.

\subsection{Model inputs and parameterization}

We applied LANDIS 4.0 to the study area and conducted a 200year simulation of each of the four alternatives. LANDIS outputs (e.g., forest composition, age classes, fire hazard, and management effects) were analysed over time. Simulated forest composition and age information were fed into a Landscape HSI Model (Larson et al., 2003) to estimate the habitat suitability for two selected indicator species, eastern wild turkey and eastern gray squirrel. All LANDIS and HSI outputs were synthesized using a multi-criteria decision-making approach (PROMETHEE, Brans and Vincke, 1985; Brans and Mareschal, 2005) to compare alternatives (Fig. 4).

For this application, the 20 ecological land types (ELTs) that Miller (1981) defined for the study area were combined to create a simplified set of seven composite ecological land types used for simulations in LANDIS (Shifley et al., 2000a,b). These land types include (Fig. 1B): (1) dry chert forest on south and west slopes, (2) forest on north and east slopes, (3) ridge tops and upland flats, (4) upland drainages, (5) mesic floodplains or low terraces, (6) slide slopes on limestone bedrock, (7) savannas/glades.

We classified tree species into four principal over-story species groups: (1) the white oak group, predominantly white oak ( $Q$. alba L.) and post oak ( $Q$. stellata Wangenh.); (2) the red oak group, predominantly black oak ( $Q$. velutina $\mathrm{Lam}$.) and scarlet oak $(Q$. coccinea Muenchh.); (3) the pine group, predominantly shortleaf pine ( $P$. echinata Mill.); and (4) the maple/mesic group, predominantly red maple and sugar maple (A. saccharum Marsh.) (Shifley et al., 2000a).

Life history characteristics for each species group (e.g., shade tolerance, fire-tolerance, sprouting probability, seed dispersal distance, and longevity) were determined from published information, primarily Burns and Honkala (1990). Forest inventory data recording the forest vegetation type and size class for each stand in the study area were coupled with regional information on tree species composition from forest inventory and analysis databases (FIA) (Hansen et al., 1992) and the nearby Missouri Ozark Forest Ecosystem Project (MOFEP) study sites (Brookshire and Shifley, 1997; Shifley and Brookshire, 2000; Shifley and Kabrick, 2002) to establish a representative species composition for each forest stand that was mapped on the modeled landscape. The spatial arrangement of species among $30 \mathrm{~m} \times 30 \mathrm{~m}$ sites within each stand was determined randomly (Fig. 2). 
Table 4

Forest management activities (per decade) and general outputs for four management alternatives.

\begin{tabular}{|c|c|c|c|c|c|}
\hline & & Alternative 1 & Alternative 2 & Alternative 3 & Alternative 4 \\
\hline \multirow[t]{4}{*}{ Even-aged timber harvest, clearcut or shelterwood } & Total harvest area (ha) & 44,897 & 41,329 & 49,443 & 55,912 \\
\hline & Total removed age cohorts & 33.1 million & 28.5 million & 30.0 million & 33.4 million \\
\hline & Total harvested age cohorts & 2.7 million & 23.7 million & 27.8 million & 27.8 million \\
\hline & Estimated cost $\left(\$ 445 / \mathrm{ha}^{\mathrm{a}}\right)$ & $\$ 20.0$ million & $\$ 18.4$ million & $\$ 22.0$ million & $\$ 24.9$ million \\
\hline \multirow[t]{4}{*}{ Uneven-aged timber harvest, group selection } & Total harvest area (ha) & 5240 & 0 & 0 & 0 \\
\hline & Total cut age cohorts & 7.5 million & 0 & 0 & 0 \\
\hline & Total harvested age cohorts & 7.5 million & 0 & 0 & 0 \\
\hline & Estimated cost $(\$ 270 / \mathrm{ha})^{\mathrm{a}}$ & $\$ 1.4$ million & 0 & 0 & 0 \\
\hline \multirow[t]{2}{*}{ Pine plantation } & Total area (ha) & 4067 & 34,983 & 18,291 & 4181 \\
\hline & Estimated cost $(\$ 391 / \mathrm{ha})^{\mathrm{b}}$ & $\$ 1.6$ million & $\$ 13.7$ million & $\$ 7.2$ million & $\$ 1.6$ million \\
\hline \multirow[t]{2}{*}{ Commercial thinning } & Total area (ha) & 19,071 & 15,243 & 13,913 & 10,127 \\
\hline & Estimated cost $(\$ 392 / \mathrm{ha})^{\mathrm{a}}$ & $\$ 7.5$ million & $\$ 6.0$ million & $\$ 5.5$ million & $\$ 4.0$ million \\
\hline \multirow[t]{2}{*}{ Prescribed burning } & Total area (ha) & 22,122 & 194,436 & 150,796 & 109,196 \\
\hline & Estimated cost $(\$ 80 / \mathrm{ha})^{\mathrm{b}}$ & $\$ 1.8$ million & $\$ 15.6$ million & $\$ 12.1$ million & $\$ 8.7$ million \\
\hline Estimated total costs $(\$)$ & & $\$ 32.2$ million & \$53.6 million & $\$ 46.7$ million & $\$ 42.1$ million \\
\hline Total harvested age cohorts & & 10.3 million & 23.7 million & 27.8 million & 27.8 million \\
\hline
\end{tabular}

a Costs were estimated based on USDA Forest Service, Mark Twain National Forest (2005). Final environmental impact statement appendices A-H, to accompany the 2005 Land and Resource Management Plan (2005 Forest Plan), 452 pp. Costs were updated to 2005 dollars.

b Costs were estimated based on USDA Forest Service, Mark Twain National Forest (1986) plan. All costs were transferred to 2005 dollars ( $\$ 1$ in $2005=\$ 0.532$ in 1984$)$.

Data on vegetation, land types and stand boundaries for nonfederal lands adjacent to and/or intermixed with national forests were lacking. Consequently we parameterized a generic oak species (or pseudo-oak species) for the forest cover of all non-federal lands. This technique allowed simulated wildfires to ignite in the nonfederal lands and spread to the National Forest and vice versa rather than arbitrarily stopping at ownership boundaries. We also parameterized a generic understory species across the entire landscape to represent herbaceous vegetation and woody understory vegetation. Although LANDIS cannot predict the dynamics of the understory vegetation, it is present on most sites and is important for modeling the spread of surface fires between stands and between owner groups. Although our simulation runs included fires that moved into and out from private lands, we restricted our summary analyses to National Forest lands where we had current, detailed information on initial forest conditions. We used fire statistics from 1970 to 1989 (Westin, 1992) to define the characters of current wildfire regime in the study area (Table 1 ).

\subsection{Habitat suitability analysis}

We applied GIS-based habitat suitability index models (Larson et al., 2003) to estimate the habitat suitability index for two species based on LANDIS output. These habitat models had previously been applied in a 3261 ha portion of forests within our study area (Larson et al., 2003; Shifley et al., 2006). The Missouri Department of Conservation and the Mark Twain National Forest have emphasized habitat for native wildlife species, and eastern wild turkey is a key species. Eastern gray squirrel is a common species in Missouri that adapts to mixed-oak forests. The habitat suitability index for eastern gray squirrel is a surrogate indicator for other small mammals that share the similar habitats. In this study, we applied the wildlife habitat suitability models to our entire study area to evaluate habitat suitability by management alternative for a 200 -year simulation.

\subsection{A multi-criteria decision-making approach (PROMETHEE)}

Multi-criteria decision analysis (MCDA) attempts to aid decision-makers in selecting among alternatives when each alternative must be judged based on a set of multiple criteria. PROMETHEE (Brans and Vincke, 1985; Brans and Mareschal, 2005) is a MCDA approach previously used in natural resource planning (Drechsler, 2004; Hermans et al., 2007). The PROMETHEE method is transparent and encourages the decision-makers rather than the program to make the final decision. The appendix includes a brief introduction to the PROMETHEE method based on Brans and Mareschal (2005).

Based on the general outputs for the four alternatives, we selected seven criteria in the decision-making process, which include: (1) estimated cost, (2) total harvested age cohorts over the 200-year simulation, (3) pine plantation area, (4) average forest value over the 200-year simulation, (5) mean fire-return interval, (6) average habitat suitability for eastern wild turkey over the 200-year simulation, and (7) average habitat suitability for eastern gray squirrel over the 200-year simulation. Since economic costs and forest products are essential to forest managers, we gave a relative high emphasis (weight $=0.25$ ) on the estimated cost and total harvested age cohorts. We simulated the habitat suitability for two index species, and each species was given an equal emphasis (weight $=0.0625$ ). All other criteria were weighted equally and given a moderate emphasis (weight $=0.125$ ). It is important to note that the relative weights used in the PROMETHEE decision support system can be altered to change the emphasis among the multiple criteria examined.

\section{Results}

\subsection{Forest management and timber harvest}

Forest management and timber harvests along the 200-year simulation were summarized for each alternative (Table 4). Estimated costs for each alternative (even- or uneven-age harvest, pine plantation, commercial thinning and prescribed burning) were calculated based on the Land and Resource Management Plan (Mark Twain National Forest, 1986, 2005). The simulated alternatives varied in total area affected by different management practices and estimated cost of treatments.

\subsection{Forest composition and age classes}

Over-story species composition was summarized by decade over the 200-year simulation and can be mapped for each decade (Fig. 5). In general, all alternatives gradually increased the coverage 
Alternative 1

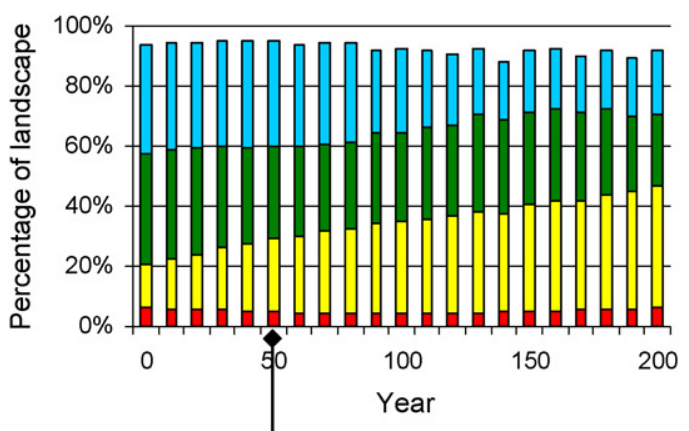

Alternative 2

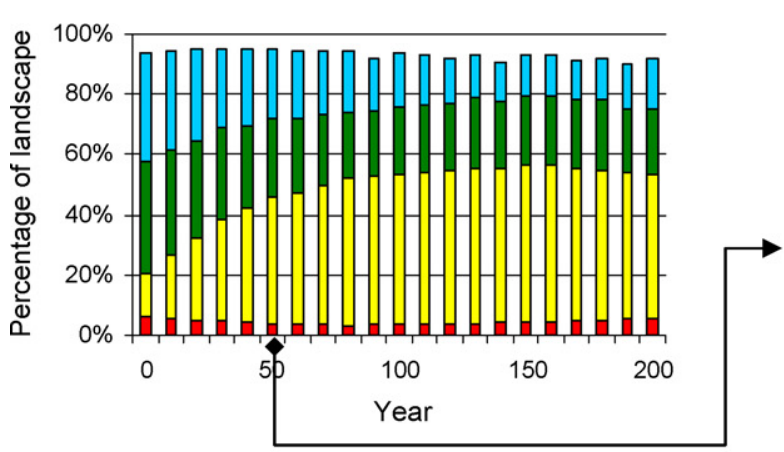

Alternative 3

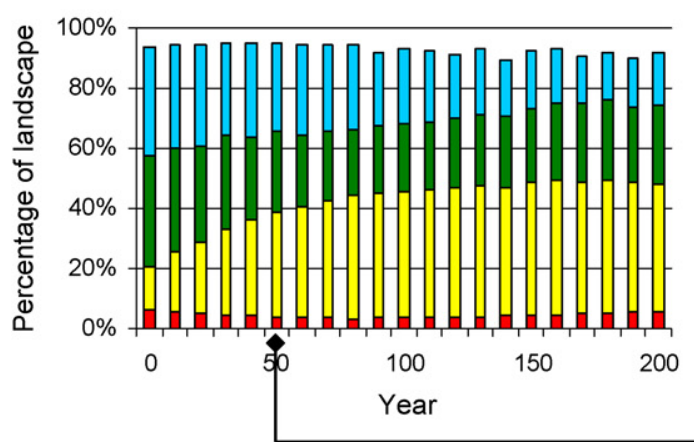

Alternative 4

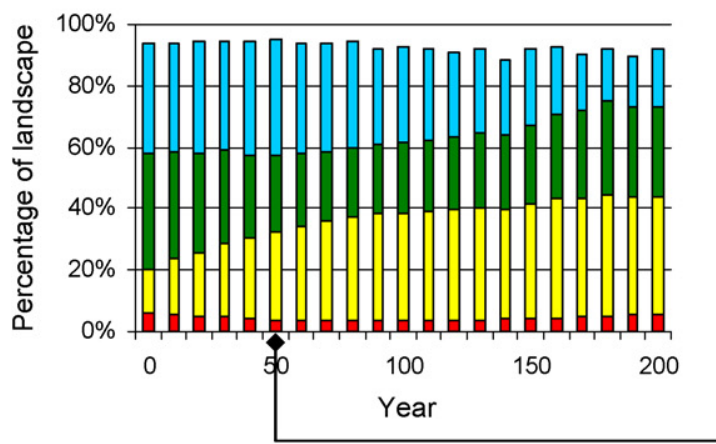

Dominant species at simulation year 50

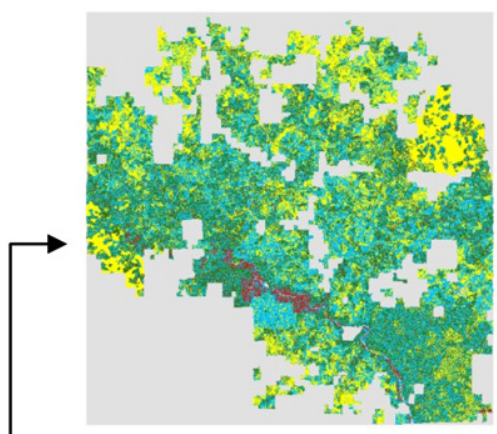

Dominant species at simulation year 50

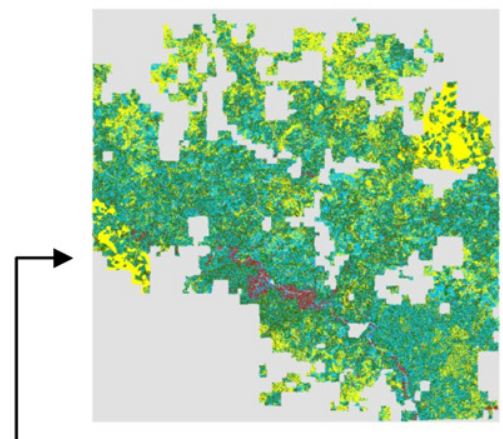

Dominant species at simulation year 50

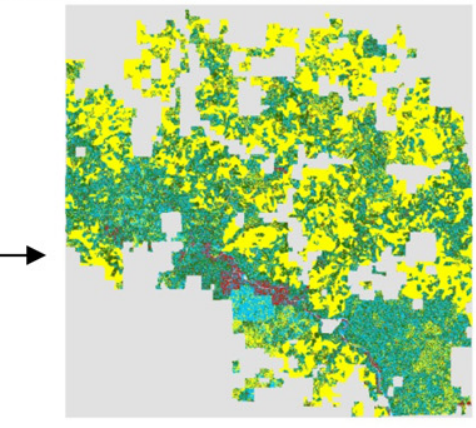

Dominant species at simulation year 50

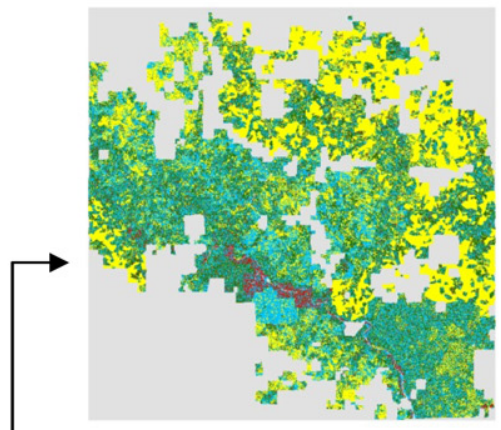

Fig. 5. Simulated distributions of dominant species under four alternatives.

of pine forests and decreased coverage of red oak. Species composition would be closer to the historic situation relative to the mid 19th century, in which the abundance of shortleaf pine was higher and the abundance of red oak was lower than present-day forests. As we know, current forest composition (low abundance or pines and high abundance of red oaks) were significantly affected by heavy logging between 1890 and 1920 (Shifley et al., 2000b) and fire suppression since 1940 (Guyette et al., 2002). Mesic/maple forests were mostly aggregated in the riparian zone along the Eleven Point National Scenic River, and did not show noticeable change among the four alternatives. Dominance of the other three species group differed among alternatives in aggregate area and spatial 


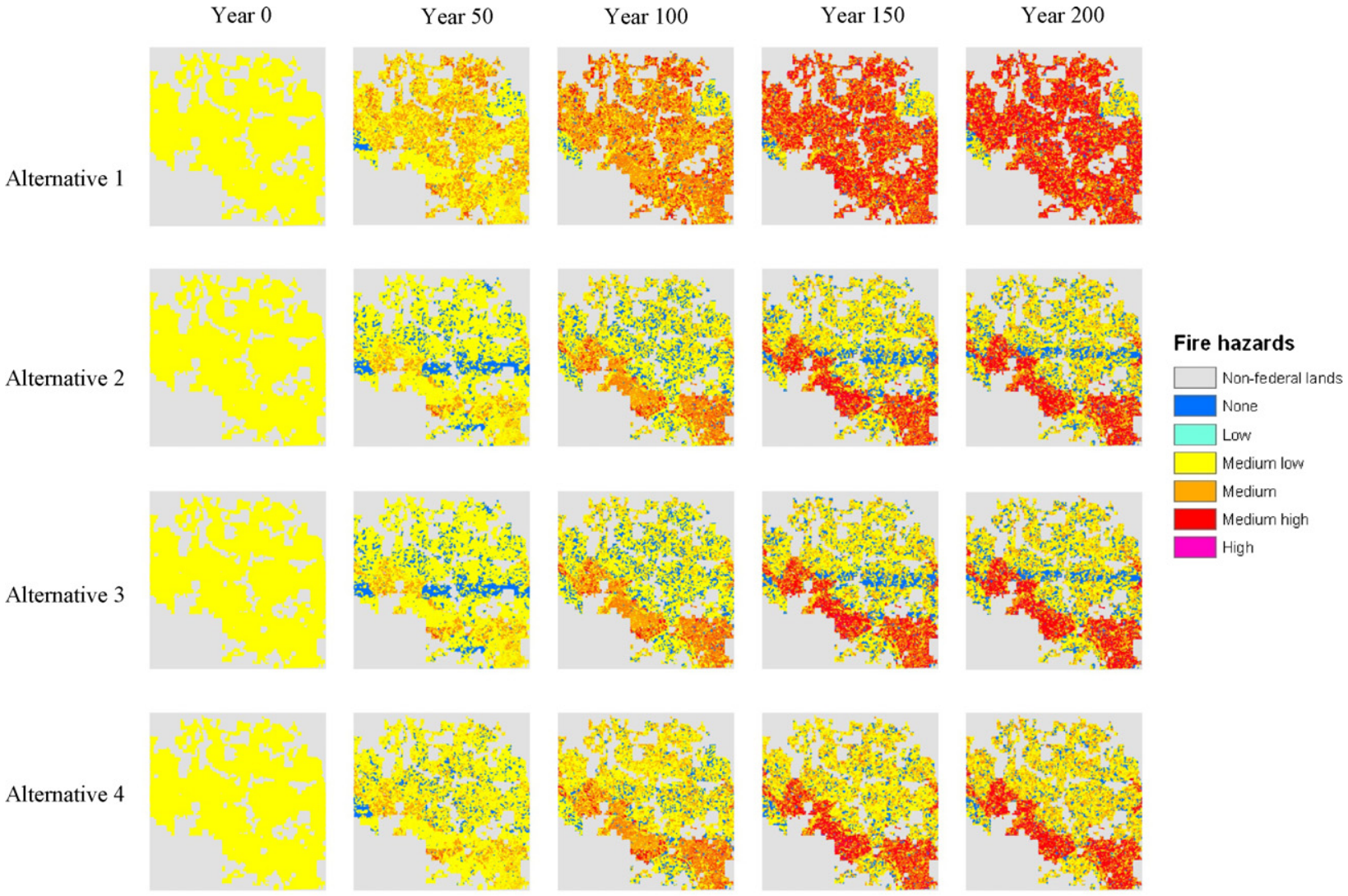

Fig. 6. Simulated fire hazards under four alternatives over 200 years period.

distribution. Although only the dominant species is illustrated for each site (Fig. 5), multiple species per site are common and the full spatial distribution of a given species (dominant or otherwise) can be mapped.

Species age cohorts were grouped into five classes, i.e., seeding ( $0-10$ years old), sapling (11-30 years old), pole (31-60 years old), sawlog (61-100 years old) and old growth (>100 years old). In general, Alternative 2 had the largest proportion of mature pine forests (old growth and sawlog forests), larger than Alternatives 3 and 4 . Alternative 1 had the smallest proportion of mature pine forests. In contrast, Alternative 2 had the smallest proportion of mature white oak forests, while Alternative 1 had the largest proportion of mature white oak forests. But the differences in mature white oak forests between those four alternatives were not as distinct as pine forests. Alternative 2 had the smallest proportion of mature red oak forests; the other three alternatives were similar for this characteristic

\subsection{Fire hazards and simulated fires}

Fire hazard, as defined as the accumulation of coarse fuel and fine fuel, were at a medium-high level in the areas along the Eleven
Point National Scenic River and the designated wilderness area in the southeast under all four alternatives. For the other areas, Alternative 1 showed a higher fire hazard level than any of the other three alternatives over the 200-year simulation (Fig. 6). After year 150 for Alternative 1, almost all the landscape had a medium-high (class 4) fire hazard. For the other three alternatives fire hazard gradually increased to a medium level over the 200-year simulation; aggregate fire hazard was lowest under Alternatives 2 and 3.

Similar patterns were found in the simulated wildfires (Table 5). Alternative 2 was most efficient in wildfire control, with the least fire frequency, smallest mean fire size and longest mean fire-return interval. Alternative 3 was better than Alternative 4 , and Alternative 1 had the highest wildfire frequency, the largest mean fire size, and the shortest mean fire-return interval.

\subsection{Habitat suitability index}

Results on habitat suitability for eastern wild turkey and gray squirrel along the 200-year simulation (Fig. 7) showed distinct difference among the four alternatives. Alternative 1 , which primarily focused on restoration, provided the highest habitat suitability for

Table 5

Simulated wildfires (not including prescribed burning) for four management alternatives.

\begin{tabular}{|c|c|c|c|c|c|c|c|}
\hline \multirow[t]{2}{*}{ Management alternative } & \multicolumn{5}{|c|}{ Number of fires by size (\# per year) } & \multirow[t]{2}{*}{ Mean fire size (ha) } & \multirow{2}{*}{$\begin{array}{l}\text { Mean fire-return } \\
\text { interval (years) }\end{array}$} \\
\hline & Total & $<0.1$ ha & $0.1-4$ ha & 4-40 ha & $>40$ ha & & \\
\hline 1 & 36.3 & 3.7 & 16.2 & 16.4 & 0 & 4.66 & 421 \\
\hline 2 & 33.5 & 4.1 & 18.1 & 11.3 & 0 & 3.68 & 576 \\
\hline 3 & 34.7 & 4.2 & 18.2 & 12.3 & 0 & 3.78 & 543 \\
\hline 4 & 35.0 & 4.5 & 18.0 & 12.6 & 0 & 3.84 & 529 \\
\hline
\end{tabular}



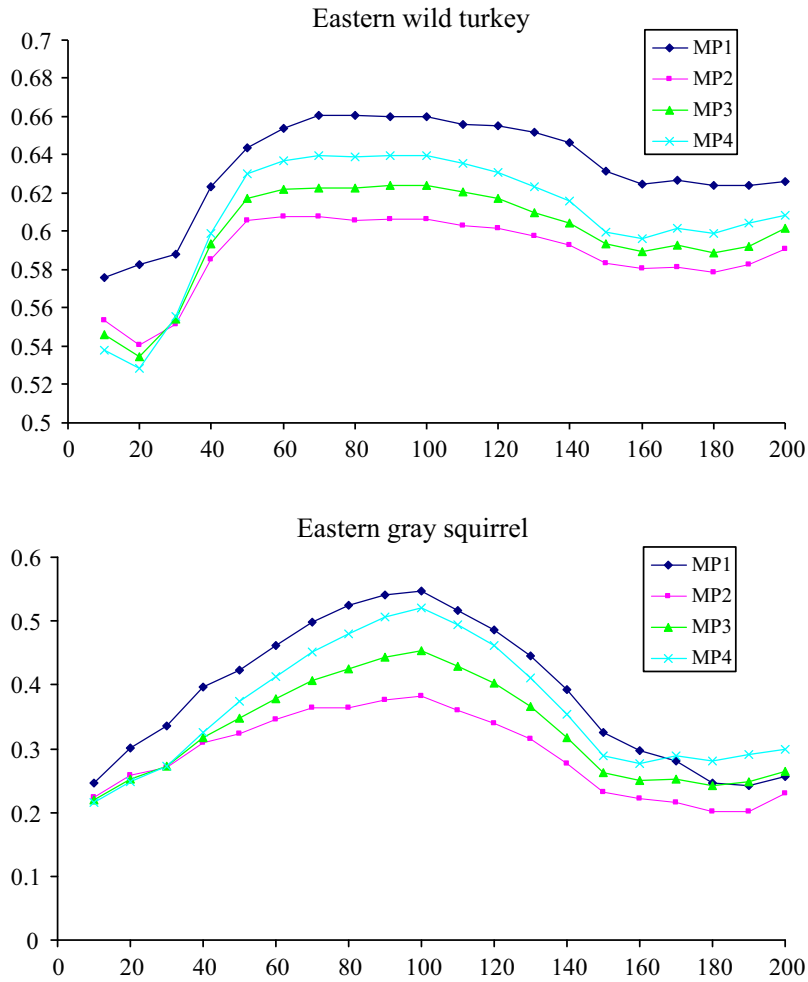

Fig. 7. Simulated average habitat suitability index for eastern wild turkey and eastern gray squirrel under the four alternatives. MP1 = Alternative 1, MP2 = Alternative 2, MP3 = Alternative 3, MP4 = Alternative 4.

eastern wild turkey and gray squirrel. Alternative 2, which emphasized restoration of oak-pine forests, provided the lowest habitat suitability for eastern wild turkey and gray squirrel. Alternatives 3 and 4 provided intermediate habitat suitability for both species over most of the simulation period.

\subsection{Decision support}

Based on above results, we summarized the general outputs for the four alternatives (Table 6), then utilized PROMETHEE to calculate the relative preference for each alternative for the specific weighting scheme described earlier. Under that weighting of outputs, Alternative 3 had the highest rank (0.44), while alternative 1 had the lowest rank $(-0.66)$. Alternative $2(0.14)$ and Alternative 4 (0.08) were intermediate.

As described in the management plans (Mark Twain National Forest, 2005), Alternative 3 was designed to balance the restoration of oak-pine forests and timber production. Model results showed that for the specified weighting scheme and the outputs that were considered, Alternative 3 has the highest preference. Alternative 2 was intended primarily for restoration and to improve the diversity of habitats and species. Alternative 4 was designed primarily for timber production with less consideration of restoration or other factors. Alternative 1 was designed mostly for natural succession with limited forest management activity. Therefore, Alternative 1 was most similar to control treatment with little human influence. Model results indicated that Alternative 1 had the lowest composite score for the variables and weighting scheme considered in the analysis.

\section{Discussion}

This study presents a novel approach that integrates forest landscape modeling, habitat suitability modeling, and a multi-criteria decision support system to quantitatively assess long-term, cumulative effects of forest management alternatives. We demonstrated the utility of this approach using a 'real world' case study. The advantages of our model integration approach include: (1) quantitative compilation and transformation of results among different models which are originally designed with different goals, (2) the ability to quantify preferences among alternatives, (3) results are relatively easy to interpret and compare, (4) transparent and explainable results that can assist local forest managers and government agencies in their science-based decision making process, and (5) capacity for sensitivity analysis and refinement of alternatives to collectively improve the quality of a complex, synthetic decisions.

This approach potentially could be applied to assist both shortterm forest management assessment and planning (e.g., future revisions of Forest Plans) and longer-term management strategic planning at the national forest level. The quantitative, structured approach could be used to model longer-term forest land changes and management alternatives that facilitate evaluation, modification, and improvement of ecological relationships. Without a structured, multi-criteria approach to decision-making, selection of a desired alterative can be difficult. In particular, linking HSI models, landscape simulation models and multi-criteria decision support system provides benefits that aggregate all these individual modeling stages for multiple forest attributes over time (Larson et al., 2004). Our approach of integrating several simulation models and analysis tools may serve as a basic framework for further research on the mark Twain National Forest and other national's forests with similar issues of habitat suitability and protection.

Most habitat suitability assessment is species-specific (Larson et al., 2003, 2004; Shifley et al., 2006). In our study, two habitat suitability index models were parameterized and applied to evaluate habitat quality over time. In fact, many other wildlife species of conservation concern could be added to the analysis, provided appropriate wildlife habitat suitably models can be developed. In addition, fire hazard management is a common and complicated issue in all forest lands. In this process, knowledge of how specific tree species and management decisions affect fires is

Table 6

General model outputs and weights used as criteria for decision-making process.

\begin{tabular}{|c|c|c|c|c|c|}
\hline \multirow[t]{2}{*}{ Criterion } & \multicolumn{4}{|c|}{ Management alternative } & \multirow[t]{2}{*}{ Weight } \\
\hline & 1 & 2 & 3 & 4 & \\
\hline Estimated cost (million \$) & 32.2 & 53.6 & 46.7 & 42.1 & $25 \%$ \\
\hline Total harvested age cohorts (million) & 10.3 & 23.7 & 27.8 & 27.8 & $25 \%$ \\
\hline Pine plantation area (ha) & 4067 & 34,983 & 18,291 & 4181 & $12.5 \%$ \\
\hline Estimated forest value (million \$) & 5.7 & 6.2 & 6.1 & 6.1 & $12.5 \%$ \\
\hline Mean fire-return interval (year) & 421 & 576 & 543 & 529 & $12.5 \%$ \\
\hline Habitat suitability for eastern wild turkey & 0.63 & 0.59 & 0.60 & 0.61 & $6.25 \%$ \\
\hline Habitat suitability for eastern gray squirrel & 0.39 & 0.29 & 0.33 & 0.36 & $6.25 \%$ \\
\hline Preference of management alternative & -0.66 & 0.14 & 0.44 & 0.08 & \\
\hline
\end{tabular}


important for modeling fire effects on forest dynamics and disturbance regimes.

Our approach has certain limitations inherited from multicriteria decision-making and spatial modeling techniques, so interpretation of the results should be done with some caution and with the knowledge of study areas. One limitation of this approach is that the core simulation model we used, LANDIS 4.0, is stochastic and fine-scale spatial patterns may differ among multiple simulation runs for the same landscape. However, for cumulative effects summarized across large landscapes the stochastic effect is small (Shifley et al., 2006; Xu et al., 2004). LANDIS and the habitat suitability models, like other similar models, are fundamentally limited by our current knowledge of the ecological processes for a given study region. Therefore, the appropriate use of this model depends on availability of required base input data for that area, success of parameterization and calibration for all the models involved in that specific region.

In addition, similar to many other multi-criteria decisionmaking approaches (e.g., Tarp and Helles, 1995), the identification of important criteria and their significance (weights) are subjective. Consequently, when the criteria are adjusted to different weights, the preference for each alternative also may be changed. Selection among alternatives could benefit from sensitivity analyses to determine how decisions would differ for a range of weighting schemes applied to the projected outcomes. Such human decisions play an important role in both choice of models, model parameterization, and interpretation of results. A related issue is fire and fuel management. While most wildfires are suppressed as quickly as possible to protect people and property, aggressive fire suppression policies and practices can allow hazardous fuels to increase over time. However, the current modeling methods permit the detailed exploration of spatial-explicit fire and fuel management alternatives. For instance, the blue horizontal strips in Fig. 6, which present low to no fire hazards in those areas as a result from simulated prescribed burning, seems not very realistic in the 'real world' and could be modified with additional assumptions about the spatial and temporal distribution of.

LANDIS has been applied in many countries and regions worldwide (Mladenoff, 2004). The ecological design of various components has been verified and validated many times. A comprehensive sensitivity analysis (Mladenoff and He, 1999) showed that the model responded reasonably to all parameter changes. A comprehensive uncertainty analysis of LANDIS shows that the simulated landscape-level properties (e.g., species percent area and their spatial patterns) were not substantially affected by the uncertainties at the cell level (Xu et al., 2004).

Validation of our result presents a challenge; just as it does for any spatial models that predict future changes. Validation in the traditional sense involves acquiring independent data for a particular time and place to compare with model predictions. Long time series of disturbance history and vegetation change data for forest landscapes do not exist for the study region and do not exist for a warming climate. Thus, it is unfeasible to conduct model validation in the traditional sense (He, 2008). However, verifying the simulation results by systematically comparing them with empirical knowledge of shorter temporal and smaller spatial extent is a reasonable way to increase confidence in our simulation results. In this study results of all four scenarios provide reasonable cause-effect relationships for trees species composition and age structure over time, verifying the utility of the simulated results.

Forest assessment, planning and management are complex processes through which people interact with natural environments (coupled human and natural system, Liu et al., 2007). Those processes become complex when planning and management deal with multiple management objectives within a forested landscape and ultimately must deal with additional factors such as land use change or climate change. Consequently, coupling landscape-scale forest vegetation and wildlife models with MCDA is an import step toward improved landscape-scale forest planning. The development and application of integrated, user-friendly, multi-criteria decision support systems designed to address forest management and planning problems provides a tool to support structured, systematic analysis of complex forest management issues.

The approach we demonstrated integrates a user-friendly multi-criteria decision support system with a forest landscape disturbance and succession model designed to address forest management and planning problems at large spatial extents and long temporal scales. We further linked the forest landscape change scenarios to wildlife habitat suitability models to add more decision criteria to the analyses. We have demonstrated the applicability of the linked system of models to a realistic landscape management planning and response scenario on the Mark Twain National Forest.

Ultimately, selection of a preferred management alternative for a national forest involves interaction of forest managers with stakeholders as they jointly consider the implications of various management alternatives. The modeling methods presented here provide a systematic method to apply the best available science to explore the long-term, large-scale cumulative effects and interactions of management alternatives on forest outputs and to link those output to multi-criteria decision support system. The capacity to synthesize the results of detailed analyses while retaining the ability to examine individual outputs in detail provides strong support for forest managers and stakeholders faced with complex management choices.

\section{Appendix A. PROMETHEE algorithm}

The following is a brief introduction to the PROMETHEE method based on Brans and Mareschal (2005).

Considering a multi-criteria problem:

$\max \left\{g_{1}(a), g_{2}(a), \ldots, g_{k}(a) \mid a \in A\right\}$

where $A$ is a finite set of possible alternatives $\left\{\alpha_{1}, \alpha_{2}, \ldots, \alpha_{i}, \ldots\right.$, $\left.\alpha_{n}\right\}$ and $\left\{g_{1}(\cdot), g_{2}(\cdot), \ldots, g_{j}(\cdot), \ldots, g_{k}(\cdot)\right\}$ a set of evaluation criteria. A set $\left\{\omega_{j}, j=1,2, \ldots, k\right\}$ represents weights of relative importance of the different criteria. Those weights are non-negative numbers, independent from the measurement units of the criteria. Based on the $j$ criteria, the preference $\left(\mathrm{PR}_{j}\right)$ of alternative an over alternative $b$ is calculated as a function of the distance between alternative $a$ and $b$ :

$\mathrm{PR}_{j}(a, b)=F_{j}\left[d_{j}(a, b)\right] \quad \forall a, b \in A$

In case of criterion $j$ to be maximized, or

$\operatorname{PR}_{j}(a, b)=F_{j}\left[-d_{j}(a, b)\right] \quad \forall a, b \in A$

In case of criterion $j$ to be minimized, where the distance is calculated as:

$d_{j}(a, b)=g_{j}(a)-g_{j}(b)$

And for which:

$0 \leq \operatorname{PR}_{j}(a, b) \leq 1$

Aggregated preference indices are calculated as: Let $a, b \in A$, and let:

$$
\left\{\begin{array}{l}
\pi(a, b)=\sum_{j=1}^{k} P_{j}(a, b) \cdot \omega_{j} \\
\pi(b, a)=\sum_{j=1}^{k} P_{j}(b, a) \cdot \omega_{j}
\end{array}\right.
$$


where $\pi(a, b)$ expresses how alternative $a$ is preferred to $b$ over all the criteria, and $\pi(b, a)$ expresses how alternative $b$ is preferred to $a$ over all the criteria.

Each alternative $a$ is facing $(n-1)$ other alternatives in $A$. The positive outranking flow $\left(\phi^{+}(a)\right)$ is calculated as:

$\phi^{+}(a)=\frac{1}{n-1} \sum_{x \in A} \pi(a, x)$

The negative outranking flow $\left(\phi^{-}(a)\right)$ is calculated as:

$\phi^{-}(a)=\frac{1}{n-1} \sum_{x \in A} \pi(x, a)$

The final rank of alternative $a(\phi(a))$ is defined as:

$\phi(a)=\phi^{+}(a)-\phi^{-}(a)$

The ranks for all alternatives can be calculated and illustrated in a numeric scale to help decision-makers to select the preferred alternative.

\section{References}

Anderson, M., Dahilin, B., Mossberg, M., 2005. The forest time machine - a multiplepurpose forest management decision-support system. Comput. Electron. Agric. 49, 114-128.

Andrews, P.L., 1986. Fire Behavior Prediction and Fuel Modeling System BURN System, Part 1, Gen Tech. Rep. INT-194. U.S. Department of Agriculture, Forest Service, Intermountain Research Station, Ogden, UT.

Baker, W.L., 1992. Effects of settlement and fire suppression on landscape structure. Ecology 73, 1879-1887.

Batek, M.J., Rebertus, A.J., Schoeder, W.A., Haithcoat, T.L., Compas, E., Guyette, R.P., 1999. Reconstruction of early nineteenth-century vegetation and fire regimes in the Missouri Ozarks. J. Biogeogr. 26, 397-412.

Beukema, S.J., Greenough, J.A., Robinson, D.C.E., Kurtz, W.A., Reinhardt, E.D., Crookston, N.L., Brown, J.K., Hardy, C.C., Stage, A.R., 1997. An introduction to the fire and fuels extension to FVS. In: Teck, M.M.J.A.R.(Ed.), Proceedings of Forest Vegetation Simulator Conference, United States Department of Agriculture, Forest Service, Intermountain Forest and Range Experiment Station, Ft. Collins, CO USA, pp. 191-1195.

Botkin, D.B., Janak, J.F., Wallis, J.R., 1972. Some ecological consequences of a computer model of forest growth. J. Ecol. 60, 849-873.

Bragg, D.C., 2000. Simulating catastrophic and individualistic large woody debris recruitment for a small riparian system. Ecology 81, 1383-1394.

Brans, J.P., Vincke, P., 1985. A preference ranking organization method, the PROMETHEE method. Manag. Sci. 31, 647-656.

Brans, J.P., Mareschal, B., 2005. PROMETHEE methods. In: Figueira, J., Greco, S., Ehrgott, M. (Eds.), Multiple Criteria Decision Analysis: State of the Art Surveys. Springer, pp. 163-195

Brookshire, B. L., and S. R. Shifley (Eds.), 1997. Proceedings of the Missouri Ozark Forest Ecosystem Project symposium: an experimental approach to landscape research. General Technical Report NC-193. U.S. Forest Service, St. Paul, Minnesota, USA.

Burns, R.M., Honkala, B.H., 1990. Silvics of North America: 1. Conifers; 2. Hardwoods Agriculture Handbook 654, vol. 2. U.S. Dept. of Agriculture, Forest Service, Washington, DC.

Church, L.R., Murray, T.A., Figueroa, A.M., Barber, H.K., 2000. Support system development for forest ecosystem management. Eur. J. Oper. Res. 121, 247-258.

Crookston, N.L., Dixon, E.G., 2005. The forest vegetation simulator: a review of its structure, content, and applications. Comput. Electron. Agric. 49, 60-80.

Crookston, N.L., Stage, A.R., 1991. User's Guide to the Parallel Processing Extension of the Prognosis Model. Gen Tech Rep INT-281. U.S. Department of Agriculture, Forest Service, Intermountain Research Station, Ogden, UT.

Dixon, G.E., 2002. Essential FVS: A User's Guide to the Forest Vegetation Simulator. Internal Rep. U.S. Department of Agriculture, Forest Service, Forest Management Service Center, Fort Collins, CO.

Drechsler, M., 2004. Model-based conservation decision aiding in the presence of goal conflicts and uncertainty. Biol. Conserv. 13, 141-164.

Ek, A.R., Monserud, R.A., 1974. FOREST: A Computer Model for the Growth and Reproduction of Mixed Species Forest Stands. Research Report A2635. College of Agricultural and Life Sciences, University of Wisconsin-Madison, Madison, WI, U.S.A

Farnden, C., 2000. Simulated conversion of unmanaged interior sprucesubalpine fir stands to a regulated uneven-aged structure. For. Chro. 76, 465-474.

Finney, M.A., 2002. Fire growth using minimum travel time methods. Can. J. For. Res. 32 (8), 1420-1424.
Finney, M.A., 1998. FARSITE: Fire Area Simulator - Model Development and Evaluation. Research Report RMRS-RP-4.U.S. Department of Agriculture, Forest Service, Rocky Mountain Research Station, Ogden, UT.

Franklin, J., Syphard, A.D., Mladenoff, D.J., He, H.S., Simons, D.K., Martin, R.P., Deutschman, D., O'Leary, J.F., 2001. Simulating the effects of different fire regimes on plant functional groups in southern California. Ecol. Model. 142 261-283.

Gilmore, D.W., 2003. To thin or not to thin: using the forest vegetation simulator to evaluate thinning of aspen. North J. Appl. For. 20, 14-18.

Gustafson, E.J., Shifley, S.R., Mladenoff, D.J., Nimerfro, K.K., He, H.S., 2000. Spatial simulation of forest succession and harvesting using LANDIS. Can. J. For. Res. 30, 32-43.

Gustafson, E.J., Zollner, P.A., He, H.S., Sturtevant, B.R., Mladenoff, D.J., 2004. Influence of forest management alternatives and land type on susceptibility to fire in northern Wisconsin, USA. Land Eco. 19, 327-341.

Guyette, R., Larsen, D., 2000. A history of anthropogenic and natural disturbance in the area of the Missouri Ozark Forest Ecosystem Project. In: Shifley, S.R., Brookshire, B.L. (Eds.), Missouri Ozark Forest Ecosystem Project Site History, Soils Landforms, Woody and Herbaceous Vegetation Down Wood, and Inventory Methods for the Landscape Experiment. USDA Forest Service General Technical Report NC-208., pp. 19-40.

Guyette, R.P., Muzika, R.M., Dey, D.C., 2002. Dynamics of an anthropogenic fire regime. Ecosystems 5, 472-486.

Haines, D.A., Main, W.A., Crosby, J.S., 1972. Forest Fires in Missouri. Research Pape NC-87. U.S. Department of Agriculture, Forest Service, North Central Forest Experiment Station, St. Paul, MN, 19pp.

Hansen, M.H., Frieswyk, T., Glover, J.F., Kelly, J.F., 1992. The Eastwide Forest Inventory Data Base: User's Manual. USDA Forest Service General Technical Report NC-151.

He, H.S., 2008. Forest landscape models: definitions, characterization, and classification. For. Ecol. Manag. 254 (3), 484-498.

He, H.S., Mladenoff, D.J., 1999a. Spatially explicit and stochastic simulation of forest landscape fire disturbance and succession. Ecology 80, 81-99.

He, H.S., Mladenoff, D.J., 1999b. Effects of seed dispersal in the simulation of longterm forest landscape change. Ecosystems 2, 308-319.

He, H.S., Hao, Z., Mladenoff, D.J., Shao, G., Hu, Y., Chang, Y., 2005b. Simulating forest ecosystem response to climate warming incorporating spatial effects in Northeastern China. J. Biog. 32, 2043-2056.

He, H.S., Li, W., Sturtevant, B.R., Yang, J., Shang, Z.B., Gustafson, E.J., Mladenoff, D.J. 2005a. LANDIS 4.0 Users Guide. LANDIS: A Spatial Explicit Model of Forest Landscape Disturbance, Management, and Succession. USDA Forest Service, General Technical Report NC-263. U.S. Department of Agriculture, Forest Service, North Central Research Station, St. Paul, MN.

He, H.S., Mladenoff, D.J., Gustafson, E.J., 2002. Simulating landscape change under forest harvesting and climate warming-induced fire disturbance. For. Ecol. Manag. 155, 257-270.

He, H.S., Shang, Z.B., Crow, T.R., Gustafson, E.J., Shifley, R.S., 2004. Simulating forest fuel and fire risk dynamics across landscapes-LANDIS fuel module design. Ecol. Model. 180, 135-151.

Hermans, C., Noordeweir, T., Sheldon, A., Erickson, J., Kline, M., 2007. Collaborative environmental planning in river management: an application of multicriteria decision analysis in the White River watershed in Vermont. J. Environ. Manag. 84, 534-546.

Hunt, L., Haider, W., 2001. Fair and effective decision making in forest management planning. Soc. Nat. Res. 14, 873-887.

Johnson, E.A., Van Wagner, C.E., 1985. The theory and use of two fire history models. Can. J. For. Res. 15, 214-220.

Johnson, K.N., Stuart, T., Crim, S., 1986. FORPLAN Version 2: An Overview.U.S. Department of Agriculture Forest Service, Washington, D.C.

Johnson, M.C., Peterson, D.L., 2005. Forest fuel treatments in western North America: merging silvicuture and fire management. For. Chro, 81, 365-368

Kangas, J., Kangas, A., 2005. Multiple criteria decision support in forest management - the approach, methods applied, and experiences gained. For. Ecol. Manag. 207, 133-143.

Kent, B., Bare, B., Field, R., Bradley, G., 1991. Natural resource land management planning using large-scale linear programming, the USDA Forest Service experience with FORPLAN. Oper. Res. 39, 13-27.

Kohm, K.A., Franklin, J.F. (Eds.), 1997. Creating a Forestry for the 21st Century: The Science of Ecosystem Management. Island Press, Washington, DC.

Kolström, M., Lumatjärvi, J., 1999. Decision support system for studying effect of forest management on species richness in boreal forests. Ecol. Model. 119, 43-55.

Lacerte, V., Larocque, G.R., Woods, M., Parton, W.J., Penner, M., 2004. Testing the Lake States variant of FVS (Forest Vegetation Simulator) for the main forest types of northern Ontario. For. Chro. 80, 495-506.

Lacerte, W., Larocque, G.R., Woods, M., Parton, W.J., Penner, M., 2006. Calibration of the forest vegetation simulator (FVS) model for the main forest species of Ontario, Canada. Ecol. Model. 199, 336-349.

Larson, M.A., Dijak, W.D., Thompson III, F.R., Millspaugh, J.J., 2003. Landscape-level habitat suitability models for twelve wildlife species in southern Missouri. In: USDA Forest Service, General Technical Report NC-233. U.S. Department of Agriculture, Forest Service, North Central Research Station, St. Paul, MN.

Larson, M.A., Thompson III, F.R., Millspaugh, J.J., Dijak, W.D., Shifley, S.R., 2004. Linking population viability, habitat suitability, and landscape simulation models for conservation planning. Ecol. Model. 180, 103-118. 
Llewellyn, W.D., Shaffer, P.G., Craig, J.N., Creasman, L., Pashley, D., Swan, M., Brown, C., 1996. A decision-support system for prioritizing restoration sites on the Mississippi River Alluvial Plain. Conserv. Biol. 10, 1446-1455

Liu, J.G., Dietz, T., Carpenter, S.R., Alberti, M., Folke, C., Moran, E., Pell, A.N., Deadman, P., Kratz, T., Lubchenco, J., Ostrom, E., Ouyang, Z., Provencher, W., Redman, C.L. Schneider, S.H., Taylor, W.W., 2007. Complexity of coupled human and natural systems. Science 317, 1513-1516.

Mark Twain National Forest, 2005. Revised Land and Resources Management Plan U.S Department of Agriculture. Forest Service, Eastern Region.

Meyer, J.L., Swank, W.T., 1996. Ecosystem management challenges ecologists. Ecol Appl. 6, 738-740.

Miller, M.R., 1981. Ecological Land Classification Terrestrial Subsystem, a Basic Inventory System for Planning and Management on the Mark Twain National Forest. U.S. Department of Agriculture, Forest Service, Eastern Region.

Mladenoff, J.D., Baker, L.W., 1999. Development of forest and landcape modeling approaches. In: Mladenoff, J.D., Baker, L.W. (Eds.), Spatial Modeling of Fores Landscape Change, Approaches and Applications. Cambridge University Press, pp. $1-13$

Mladenoff, J.D., He, S.H., 1999. Design, behavior and application of LANDIS, an objectoriented model of forest landscape disturbance and succession. In: Mladenoff, J.D., Baker, L.W. (Eds.), Spatial Modeling of Forest Landscape Change, Approaches and Applications. Cambridge University Press, pp. 125-162.

Mladenoff, D.J., 2004. LANDIS and forest landscape models. Ecol. Model. 180, 7-19.

Mladenoff, D.J., Host, G.E., Boeder, J., Crow, T.R., 1993. LANDIS: a model of forest landscape succession and management at multiple scales. Proceedings of the Annual US Landscape Ecology Symposium. Oak Ridge, TN, USA, p. 77.

Mladenoff, D.J., Host, G.E., Boeder, J., Crow, T.R., 1996. LANDIS: a spatial model of forest landscape disturbance, succession, and management. In: Goodchild, M.F., Steyaert, L.T., Parks, B.O. (Eds.), GIS and Environmental Modeling: Progress and Research Issues. GISWorld Books. Fort Collins, CO, USA, pp. 175-180.

Mudrick, D.A., Hoosein, M., Hicks Jr., R.R., Townsend, E.C., 1994. Decomposition of leaf litter in an Appalachian forest: effects of leaf species, aspect, slope position and time. For. Ecol. Manag. 68, 231-250.

Nigh, T.A., Schroeder, W.A., 2000. Atlas of Missouri Ecoregions. Missouri Department of Conservation.

Pacala, S.W., Canham, C.D., Silander Jr., J.A., 1993. Forest models defined by field measurements. I. The design of a northeastern forest simulator. Can. J. For. Res. 23, 1980-1988.

Rauscher, H.M., 1999. Ecosystem management decision support for federal forests in the United States: a review. For. Ecol. Manag. 114, 173-197.

Reinhardt, E.D., Keane, R.W., Brown, J.K., 1997. First Order Fire Effects Model: FOFEM 4.0, User's guide. USDA Forest Service, General Technical Report, EIIT-GTR-344. U.S. Department of Agriculture, Forest Service, Intermountain Research Station, Ogden, UT.

Roberts, W.D., Betz, W.D., 1999. Simulation landscape vegetation dynamics of Bryce Canyon national Park with the vital attributes/fuzzy systems model VAFS/LANDSIM. In: Mladenoff, J.D., Baker, L.W. (Eds.), Spatial Modeling of Fores Landscape Change, Approaches and Applications. Cambridge University Press, pp. 99-124.

Schwalm, C.R., Milner, K.S., 2002. Stand responses following partial cutting in western Montana. West. J. Appl. For. 17, 37-45.

Seely, B., Nelson, J., Wells, R., Peter, B., Meitner, M., Anderson, A., Harshaw, H. Sheppard, S., Bunnell, F.L., Kimmins, H., Harrison, D., 2004. The application of a hierarchical, decision-support system to evaluate multi-objective forest management strategies: a case study in northeastern British Columbia, Canada. For. Ecol. Manag. 199, 283-305.

Shang, Z.B., He, H.S., Crow, T.R., Shifley, R.S., 2004. Fuel load reductions and fire risk in central hardwood forests of the United States: a spatial simulation study. Ecol. Model. 180, 89-102.
Shifley, S.R., Thompson III, R.F., Dijak, D.W., Larson, A.M., Millspaugh, J.J., 2006. Simulated effects of forest management alternatives on landscape structure and habitat suitability in the Midwestern United States. For. Ecol. Manag. 229, 361-377.

Shifley, S.R., Thompson III, F.R., Larsen, D.R., Mladenoff, D.J., Gustafson, E.J.,2000a. Utilizing inventory information to calibrate a landscape simulation model. In: Proceedings of Integrated Tools for Natural Resources Inventories in the 21st Century, 1998. USDA Forest Service, General Technical Report. NC-212. U.S. Department of Agriculture, Forest Service, North Central Research Station, St. Paul, MN.

Shifley, S.R., Thompson III, F.R., Larsen, D.R., Dijak, W.D., 2000b. Modeling forest landscape change in the Missouri Ozarks under alternative management practices. Comput. Electron. Agric. 27, 7-24.

Shifley, S.R, Brookshire, B.L. (Eds.), 2000. Missouri Ozark Forest Ecosystem Project: site history, soils, landforms, woody and herbaceous vegetation, down wood, and inventory methods for the landscape experiment. General Technical Report NC-208. The United States Department of Agriculture, Forest Service, North Central Research Station. St. Paul, MN.

Shifley, S.R., Kabrick, J.M. S, 2002. In: Proceedings of the Second Missouri Ozark Forest Ecosystem Symposium: Post Treatment Results of the Landscape Experiment. General Technical Report NC-227. St. Louis, MO, October 17-20, 2000 U.S. Department of Agriculture, Forest Service, North Central Forest Experiment Station, St. Paul, MN, 228p.

Shugart, H.H., 1984. A Theory of Forest Dynamics: the Ecological Implications of Forest Succession Models. Springer-Verlag, New York.

Tarp, P., Helles, F., 1995. Multi-criteria decision-making in forest management planning - an overview. J. For. Econ. 1 (3), 273-306.

Teck, R., Moeur, M., Eav, B., 1996. Forcasting ecosystems with the forest vegetation simulator. J. For. 94, 7-10.

Torgersen, T.R., 2001. Defoliators in eastern Oregon and Washington. Northwest Sci. $75,11-20$.

Treiman, T., Dwyer, J., Larsen, D., 2005. Long-term economic simulation: even-aged and uneven-aged examples from the Missouri Ozark Forest Ecosystem Project (MOFEP). North J. App. For. 22, 42-47.

Trofymow, J.A., Moore, T.R., Titus, B., Prescott, C., Morrison, I., Siltanen, M., Smith, S. Fyles, J., Wein, R., Camire, C., Duschene, L., Kozak, L., Kranabetter, M., Visser, S., 2002. Rates of litter decomposition over 6 years in Canadian forests: influence of litter quality and climate. Can. J. For. Res. 32, 789-804.

Varma, K.V., Ferguson, I., Wild, I., 2000. Decision support system for the sustainable forest management. For. Ecol. Manag. 128, 49-55.

Weintraub, A., Jones, G., Magendzo, A., Meacham, M., Kirby, M., 2004. A heuristic system to solve mixed integer forest planning models. Oper. Res. 42, 1010-1024.

Westin, S., 1992. Wildfire in Missouri. Missouri Department of Conservation, Jefferson City, MO, $161 \mathrm{pp}$.

Wykoff, W.R., Crookston, N.L., Stage, A.R., 1982. User's Guide to the Stand Prognosis Model. USDA Forest Service, General Technical Report, INT-133. U.S. Department of Agriculture, Forest Service, Intermountain Forest and Range Experiment Station, Ogden, UT.

Xi, W., Coulson, R.N., Waldron, J.D., Tchakerian, M.D., Lafon, C.W., Cairns, D.M., Birt, A.G., Klepzig, K.D., 2008. Landscape modeling for forest restoration planning and assessment: lessons from the southern Appalachian Mountains. J. For. 106 (4), 191-197.

Xi, W., Coulson, R.N., Birt, A.G., Shang, Z.B., Waldron, J.D., Lafon, C.W., Cairns, D.M., Tchakerian, M.D., Klepzig, K.D., 2009. Review of forest landscape models: types, methods, development and applications. Acta Ecol. Sin. 29 (1), 69-78.

Xu, C., He, H.S., Hu, Y., Chang, Y., Larsen, D.R., Li, X., Bu, R., 2004. Assessing the effect of cell-level uncertainty on a forest landscape model simulation in Northeastern China. Ecol. Model. 180, 57-72.

Yang, J., He, H.S., Gustafson, J.E., 2004. A hierarchical statistical approach to simulate the temporal patterns of forest fire disturbance in LANDIS model. Ecol. Model. $180,119-133$. 